\title{
W. G. Sebald's Late Lyrics Between Words, Images and Languages
}

\author{
AXEL ENGLUND
}

\begin{abstract}
W. G. Sebald wrote and published poetry from the early 1960s until his death in 2001. Even though Sebald's oeuvre is among the most extensively studied in Germanistik today, however, his lyric poetry remains in the shadow of his prose and has yet to be afforded extensive critical attention. Working on what was to be his last novel, Sebald appears to have devoted more time to poetry than previously, which resulted in several publications: For Years Now (2001), a collection of micropoems juxtaposed with images by the British painter Tess Jaray, and Unerzählt (2003), a set of similar poems in German, published together with etchings by the artist Jan Peter Tripp. The present article takes as its point of departure the observation that these two books overlap substantially - many of the poems exist in several versions none of which can be said to be the definitive one - and attempts to interpret a selection of poems with a particular view to their material, linguistic and intermedial particularities. Using the concept of differential poetry, a term coined by Marjorie Perloff, it asks what meanings may emerge from Sebald's sparse verses when the subtle variations between the different versions - caused by versification, typography, translation, and word-and-image interplay - are brought to the fore.
\end{abstract}

Keywords: W.G. Sebald, Tess Jaray, Jan Peter Tripp, For Years Now, Unerzählt, poetry, painting, intermediality

W. G. Sebald wrote poetry regularly for around forty years, and towards the end of his life, after the enormous success of novels like Die Ringe des Saturn and Austerlitz, he seems to have devoted more of his attention to the genre. The last book he published before his fatal car accident in 2001 was a collection of English-language "micropoems" - as the author himself called them (Schütte 2013: 113) - interspersed with paintings by the British artist Tess Jaray, and another collaborative project with the painter Peter Tripp was in the making, although Tripp had to finalize by himself the book Unerzählt of 2003. Until recently, however, Sebald's poetry had not been given any substantial treatment, in spite of the fact that Germanists have long been extending their 
interest beyond the prose masterpieces. ${ }^{1}$ His poetry has been considered dubious Apocrypha rather than canonical Scripture: it is typically described only as an appendage - for instance, as a "primer" (Adams 2004), a "prelude", a "preface", an "afterthought" (Görner 2003: 75, 80) - to his prose.

One possible reason for this is that many of the poems seem to be reworkings of each other, which gives them a quality of the indecisive and unfinished: images and formulations reoccur, and sometimes several micropoems seem to have their origin in earlier, longer, ones (see Schütte 2013, 122 127). Numerous poems in For Years Now are English translations of the ones published in Unerzählt, although often with slight differences. Some readers have perceived this state of affairs as troublesome. As a notable example, one might mention Michael Hamburger, Sebald's long-time friend and translator. In the preface to his translation of Unerzählt, he dwells above all on its strange and disconcerting relation to the poems of For Years Now. He warns that "English speaking readers of this book could be puzzled or disappointed to find that a number of these texts overlap with those included in Sebald's earlier collaboration", and confesses that "this and other complications worried me" (Sebald 2004: 7). Both Tripp and Jaray, moreover, appear to have been equally confounded by the existence of the versions in another language, of which Sebald had never told either artist (Sebald 2004: 8; Schütte 2013: 113).

In view of Sebald's reticent attitude to these poems, and the indecisive or tentative quality suggested by the parallel versions, it is perhaps unsurprising that they have habitually been perceived as an attempt at a genre that Sebald did not really know what to do with. Another possibility, however, is that he knew very well what he was doing, and that the particular unfinishedness of his poetic work was a deliberate strategy to cope with a genre that he thought deeply problematic. Like Adorno and others, Sebald perceived the lyric as a bourgeois genre that had become severely questionable after the Second World War. Uwe Schütte has pointed to a 1971 article on Günter Eich - one of the few critical pieces Sebald ever wrote on a well-known poet - which states the following:

The scholarly publications on Sebald's lyric poetry to this date are limited to Corkhill 2009, Englund 2013, 2014a and 2014b, Görner 2003, Hamburger 2007, and the pioneering Schütte 2013, which is the first monograph on the subject. The afterwords to Sebald 2003 and 2008 (by A. Köhler and S. Meyer, respectively) also deserve mention, as does Galbraith's introduction to the English translation of the former volume (Sebald 2011). 
Von vornherein - auch wo sie wider Erwarten noch gelingt - ist Lyrik mit den Merkmalen des Postexistenten, längst schon Überfälligen gezeichnet. Schwerlich läßt sich daraus folgern, das Gedicht, dessen Schönheit einmal die Hoffnung auf Dauer bedeutete, sei inzwischen zu etwas Amoralischem geworden; jedoch existiert es mit demselben zweifelhaften Recht, mit dem auch die Gesellschaft, nach allem, was sie anrichtet, immer wieder überlebt. (Quoted in Schütte 2013: 16)

Even though this text was written three decades before the micropoems of the late nineties, it would appear that these formulations retained a certain relevance to Sebald. The conclusion that he reaches is as laconic as it is telling: "Dichten ist nicht mehr erlaubt, kritzeln schon." (Schütte 2013: 16). Poetry, from this perspective, must deliberately avoid the ambition to endure as an eternal masterpiece, and scale itself down to a scribble. If this perspective on poetry remained with Sebald to the end of his life, the "seeming casualness" of the late poems' "reductive epiphanies", noted by Hamburger, may begin to make sense in a different way (Sebald 2004: 7).

The point I wish to make in this article is that this appearance of casualness does not make the task of close interpretation superfluous: on the contrary, the clash between the traditionally meaning-laden genre of the lyric, and the appearance of the offhand and mutable in Sebald's micropoems creates a particular hermeneutic situation that demands a particular kind of precision. I have found it helpful to think of them in terms of what Marjorie Perloff has termed "differential texts", that is, "texts that exist in different material forms, with no single version being the definitive one" (Perloff 2006: 146). Like the texts that Perloff refers to - which exist in both digital and print form - the different versions of Sebald's poems constitute a resistance to the impulse to view them as disembodied text, the linguistic and material guise of which is merely incidental. Rather, I would argue, their meaning is articulated by the difference between the textual versions, between German and English, and between the verbal and the visual. If hermeneutic construal is to be a valid approach to "differential" poems like Sebald's, it needs to execute its interpretative performance in light of the details of their linguistic, generic, medial and material embodiment, and without neglecting the intimate interrelations between many of them. This article is an attempt at such interpretation.

For Years Now, the English-language collection with images by Tess Jaray, was published on December 32001 , only weeks before Sebald's death (Schütte 2013: 111). The initiative for this book was Jaray's, as was the finalized product. They first met in March 2000, to discuss a series of paintings that Jaray had conceived with passages from Schwindel.Gefühle and Die Ringe des Saturn in 
mind (Jaray 2010: 20). Sebald, who was intrigued by Jaray's paintings of intense colour and geometrical patterns as well as by her background as the daughter of Austrian Jews in exile, agreed to furnish her with a series of as yet unpublished poems and left the composition of the book itself in Jaray's hands (Schütte 2013: 117). The result is a small (6 by 7.8 inches), soft-cover volume, in which 23 poems are juxtaposed with as many paintings. Jaray's images typically display either a monochrome pattern against a white backdrop, or a monochrome ground against which a white pattern - a grid, a grille, a lattice stands in relief.

The etchings of Tripp, which accompany the German poems in Unerzählt, could not be more different. Tripp's images are black-and-white etchings, each of which depicts a pair of eyes (belonging to various writers, artists and acquaintances, as well as the two originators of the book). The naturalism of the images openly acknowledges its debt to photography, and their straightforward figurativity is a far cry from Jaray's abstract patterns. The narrow isolation of the eyes from the faces to which they belong gives each gaze an intense and somewhat claustrophobic quality. The physical appearance of the volume is also quite different from For Years Now. Unerzählt is in a larger format (7 by 11.4 inches) and more expensive-looking edition, bound in grey cloth, and with a transparent dust jacket. In this volume, too, the final product, including the pairings of images and words, is the work of the visual artist (who takes care to point out this fact, as well as the fact that the collaboration had been planned for several years) (see Sebald 2003: front matter). Even more than the Jaray book, Unerzählt seems to demand a reverently bibliophile attention, as an object boasting its aesthetic value.

\section{Colour and Achromatopsia}

In Jaray's arrangement of the poems, the first four make mention of specific colours: red and green, brown, blue, and then red once more. The paintings mostly follow suit (although not entirely): after the intense bright cinnabar of the cover, they line up in turn a strong pear green, a mauve taupe and a dark purple, before the red cover painting reappears. Poems and paintings thus join in an exposition of basic colours, as if to take as its point of departure the primary facts of vision. Even in the first poem, however, this ostensibly simple differentiation is thrown into doubt, conjuring up the state of uncertainty that is so often the focal point of Sebald's poetry: 
W. G. Sebald's Late Lyrics Between Words, Images and Languages

It is said

Napoleon was
colourblind
\& could not
tell red
from green

(Sebald 2001: 9)

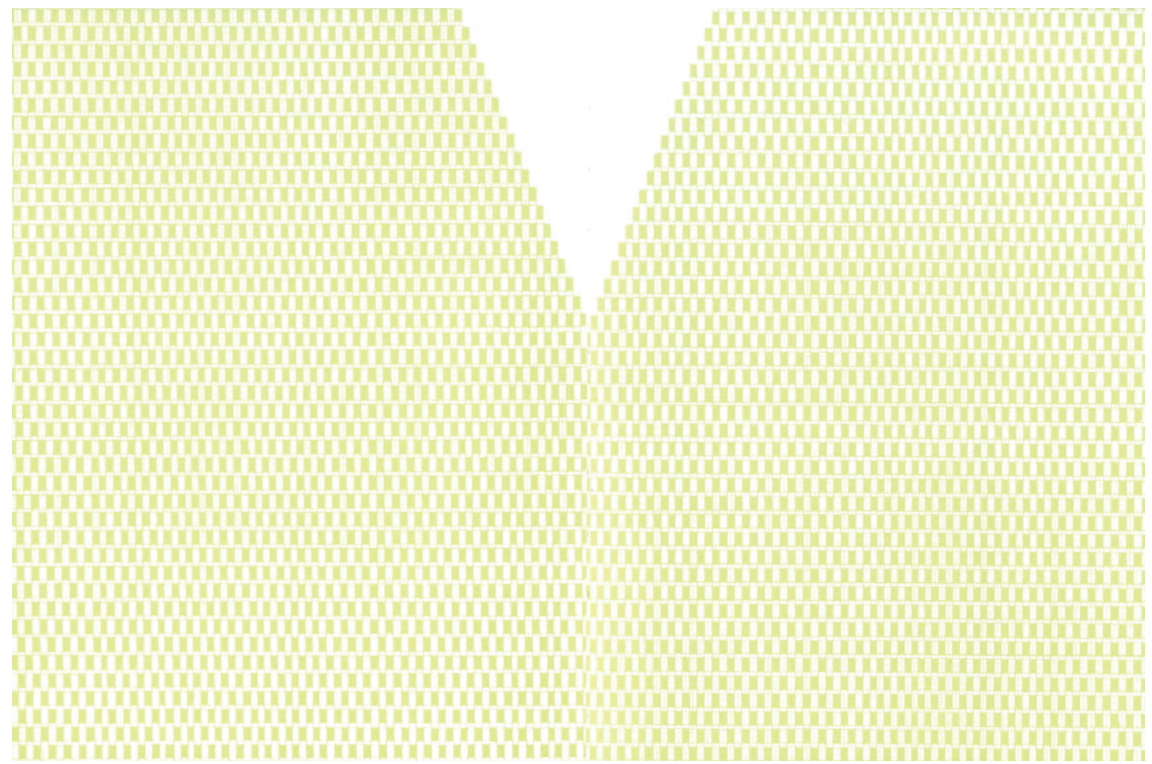

Fig. 1. Tess Jaray, painting accompanying the poem "It is said" (Sebald 2001: 10-11)

The emperor's purported dysfunction stands in relief against the colours that surround the opening poem in the book: before or around it the red painting of the cover, after it a painting with a symmetrical pattern of microscopic pear green and white rectangles (fig. 1). The colours distinguished by the reader, then, are those named in the poem as indistinguishable in the eyes of Napoleon. The ambiguity thus suggested in the visual register is paralleled in the verbal register, as the first three words of the collection signal an 
unsubstantiated rumour: "It is said". ${ }^{2}$ As such, they place the poem under a heading of uncertainty, which lets an epistemological doubt stand side by side with the aesthetic confusion: the inability to conclusively judge an utterance as false or true corresponds to the inability to discriminate between colours.

This thematization of perception in the realms of the verbal and visual is a recurrent theme in For Years Now (and, for that matter, in Unerzählt). Consider for instance the collection's third poem:

Blue
grass
seen
through
a wafer
thin layer
of frozen
water

(Sebald 2001: 15)

Here, the blank line between the first word and the poem is the source of semantic ambiguity. If "Blue" is thought of as a title, the rest of the poem defines that blue as the result of a filtered perception: it is the colour perceived when grass is seen through a thin layer of ice. If "blue" is simply an attributive adjective to "grass", however, the filter is bypassed or transparent, and the grass is actually of that colour. What the space between "blue" and "grass" accomplishes, then, is to let the poem hover between colour as an objective quality and as a perceptive projection contingent on a particular filter. The connotations of depression, coldness and hardness that come with the blue and the frozen, moreover, suggests a negative emotional state as the cause of that filter.

The grass and the green, of course, have a natural connection that is not easy to dissolve: each brings the other with it, in a movement that the poem "Blue" seeks to interrogate or short-circuit. Arguably, Jaray does something similar in the painting that accompanies the Napoleon poem. In her eyes, green is a strange colour:

2 It is indeed unsubstantiated: the idea of Napoleon's inability to tell red from green stems from an amateur historian from Brussels, by the name of Alfonse Huyghens, whom Sebald accorded some attention in Campo Santo (Schütte 2013: 129). 
W. G. Sebald's Late Lyrics Between Words, Images and Languages

Well, strange perhaps only when not used in landscape subjects, where it appears proper and correct, and confirms everything that we observe. But when it is not 'attached' to an object, when there is no recognisable piece of nature to relate to its use, it seems to become something else. [...] Of course, one of the problems is avoiding, if that's what you want to do, the obvious association with nature. Why would you want to do this? Perhaps to create moods or senses that are as purely themselves as they can be, without interference from the outside world, without any association that would deplete or diminish the power of the colour itself. (Jaray 2010: 34)

Does Jaray's own painting to this poem (fig. 1) avoid the associations with nature? Not necessarily: it may be taken to suggest two steep hills or mountains, with a white piece of sky shining through the gorge between them. Jaray's images continuously display an interest in retaining the possibility of reference - which in the case of green seems to move more or less automatically toward chlorophyll and vegetation - while still pursuing chromatic purity. This ambiguity is a theme that repeatedly comes to prominence in the space between her paintings and Sebald's micropoems.

If green is at home in the representation of nature, red - which in Jaray's words "contains so much passion and emotion, so much immediacy and exuberance" (Jaray 2010: 34) - has a similar referential pull toward the human body, and its inside in particular. The complementarity of the colours in Sebald's Napoleon poem could thus be taken to point to the interrelation of nature and humanity, which is so often the focus of Sebald's texts. The Enlightenment values that engendered Napoleon, for instance, were zealously committed to man's subjugation of nature. If the difference between these colours becomes blurred, no difference remains between the subjugation of nature and that of human bodies. This perspective is made explicit in the German version of this poem, published in Unerzählt and collocated with one of Tripp's etchings of a pair of eyes (fig. 2):

\author{
Es heißt \\ daß Napoleon \\ farbenblind war \\ \& Blut für ihn \\ so grün wie \\ Gras
}

(Sebald 2003: 49) 


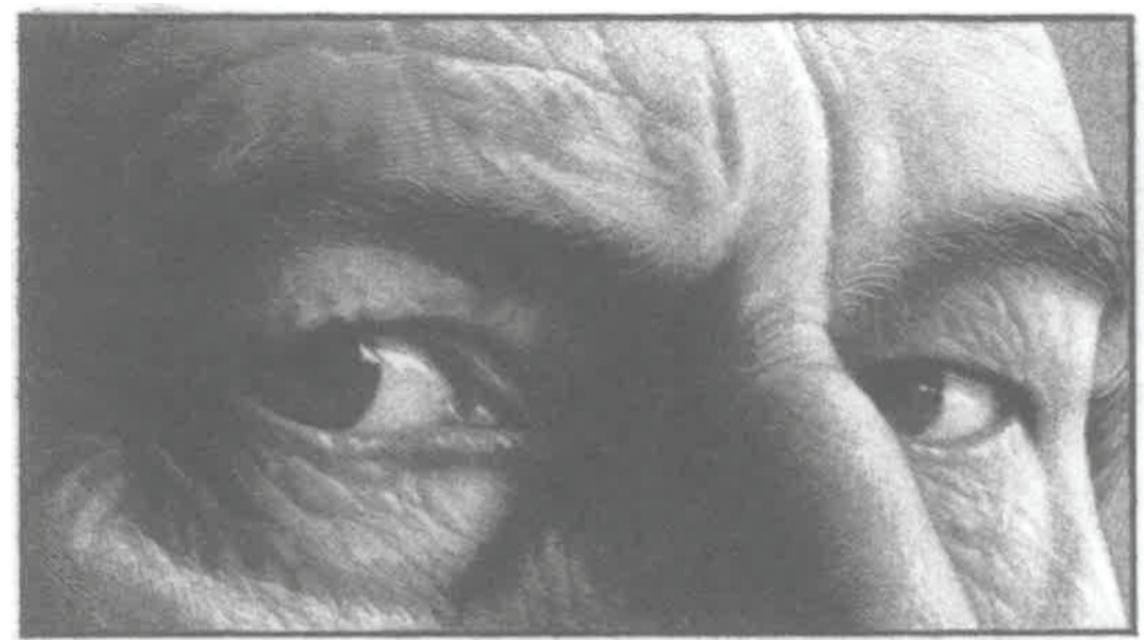

Fig. 2. Jan Peter Tripp, etching accompanying the poem "Es heißt" (Sebald 2003: 48)

Reading this poem after the English version, I would suggest, need not entail a revelation of what the poem "actually" means. My point here is that the second poem does not make blood and grass the proper referents of the English poem, "grün wie / Gras" thus eclipsing the simple "green”. Instead, what the collocation of these poems brings to the fore is, precisely, the difference between an unspecified, pure green and one that is part of a natural landscape, or between reference as a subtle echo and as an unambiguous statement. The English poem is quasi-blind to figurativity, as it were: it utters colour pure and simple, while simultaneously drawing attention to its impurity and complexity. In the German poem, by contrast, figurativity takes precedence over pure colour: it speaks not of red but of blood, and the green is explicitly that of grass. Reading them together - as a differential poem - places the emphasis not on either text, but on the gap between them.

The difference is notably paralleled by the images. The possible figurativity of Jaray's painting is of an understated kind, directed primarily at the colour green itself, although remaining mindful of nature's tendency to accompany it as a visual echo, as does the interior of the human body with red. In Tripp's pair of eyes, meanwhile, figurativity is never in question. Instead, his images thematize the presence or absence of a subjective filter of perception by a superimposition of two visual media, around which opposing connotations cluster: their origin in photography is just as openly announced as the painstaking craft of etching. The stereotypical association of indexical objectivity that has always 
remained attached to photography - even though the medium has never been unproblematically transparent - is thus continuously counterbalanced by the visible manual labour that guarantees the intervention of a human subject in the resulting representation. Sebald, in his own essay on the works of Tripp, printed in Logis in einem Landhaus, emphasizes the latter aspect:

Das photographische Material, von dem sie ihren Ausgang nehmen, wird sorgfältig modifiziert. Die mechanische Schärfe/Unschärferelation wird aufgehoben, Hinzufügungen werden gemacht und Abstriche. Etwas wird an eine andere Stelle gerückt, hervorgehoben, verkürzt oder um eine Geringfügigkeit verdreht. Farbtöne werden verändert, und es unterlaufen bisweilen auch jene glücklichen Fehler, aus denen sich dann unversehens das System einer der Wirklichkeit entgegengesetzten Darstellung ergibt. (Sebald 2000: 179)

The static drama of these images, in other words, takes place where the idea of mechanically objective lens chafes against that of the subjectively inflected gaze (or the distorted perception) of the human hand and eye.

While the figurativity of Tripp's images is obvious, the question of how the particular image relates to the particular poem is not (the pair of eyes across from this poem are those of Michael Krüger, the publisher of the book and executive of Hanser Verlag). Yet when focusing on this specific poem, it is difficult not to let its notion of achromatopsia refer to the achromatic images of eyes (especially when the clear colours of Jaray's paintings are held in mind as a counterpart). The black-and-white look that the reader encounters becomes an image of collective colour blindness: the book itself, as well as its readership, is implied in the visual dysfunction - to read Unerzählt is to temporarily block out chromatic difference - which, unsettlingly enough, includes the connotations of mass death absurdly ascribed to that dysfunction in this version of the Napoleon poem.

\section{The Eye, the I and the Ear}

Let me continue with another example from For Years Now, a poem of only eighteen words, beginning from a slightly different aspect of the poem's appearance, namely that of typography: its arrangement on the page, its lines breaks, and the capacity of these aspects to open up new possibilities of interpretation. 
ENGLUND

\author{
It was as if \\ I was lying \\ under a low \\ sky breathing \\ through the eye \\ of a needle
}

(Sebald 2001: 57)

This poem, like all others in For Years Now and Unerzählt, consists of a grammatically complete and immediately comprehensible phrase. Hypothetically, it could function just as well in prose, as a metaphorical description of an uncannily claustrophobic situation. The lyrical I is threatened by suffocation as the sky presses against it, and the breathing hole is no bigger than a needle's eye. The image is an intertextual evocation of various religious sources, where it serves as an image for that which is impossible to penetrate. Thus read, the poem would be interchangeable not only with a prose sentence, but also with the corresponding German poem in Unerzählt:

\author{
Es ist \\ als läge ich \\ unter einem niedrigen \\ Himmel \& atmete \\ durch ein Nadelöhr
}

(Sebald 2003: 33)

As should be clear by now, however, my focus in this article is not on the common ground of these versions, but on that which differentiates them from each other. Which meanings may the poem yield if that which is seemingly fortuitous and marginal rather than obviously intended is brought into focus? The "may" is significant: the search for meaning includes the question of what is allowed to matter. As I suggested in the introduction, one of the most characteristic traits of Sebald's micropoems is the confrontation between the seemingly casual tone and the poetic genre's meticulous attention to detail and meaning. Both of these poles are patently present in the poems as they are embodied within the two artists' books: all the poems have the look of 
impromptu notes, jotted down on the spur of the moment, yet their concrete embodiment in the printed book works against this casualness. Already when looking at one of the poems from a distance, we see the image of a genre that belies the straightforward reading as a prose sentence: the surrounding white space, the short lines and the arrangement of the verses all function as a visual representation of lyric poetry. By the conventions associated with that genre, this impression suggests that a different attention, with a greater interest in complexity of detail, might be warranted.

For instance, in "It was as if", the frequent interruption of the sentence by its division into segments of two or three words may be read as an emulation of a speaker short of breath, the versified form of the poem thus mirroring the predicament evoked by the content. But more than that, the versification perforates the wholeness of the sentence and lets a multitude of conflicting meanings issue from its fissures. Again, the four first words are separated from the rest of the text by a conspicuous gap, and thereby take on the function of a title: "It was as if". By superscribing the poem with this line, Sebald instigates the interplay of reality and metaphorical representation and suggests that it is a core concern of the text (and thus parallels the function of "It is said").

If, in the title, the ontological certainty of the verb "was" is undermined by the "as if", the homographic ambiguity of the next line - "I was lying" - sharpens this notion from figurality to outspoken falsification, bringing the problem of linguistic representation to the fore. Read in similar isolation, the third line "under a low" - might come across as a hyperbole: a position not only low, but below the low. Next, the fourth line disturbs the apparent simplicity of the subject-predicate relation: while the immediate sense of the sentence posits the "I" as the breathing subject, the isolation of "sky breathing" on a line of its own suggests the possibility that the breath is that of the sky itself, thus adding anthropomorphism to the sequence of tropes.

Next, vision itself is explicitly thematized in the penultimate line, as the images pass "through the eye" (an eye that does not become that of a needle until the final word of the poem). The subjectivity of personal vision and its fundamental impact on linguistic communication is further emphasized by the homophonic pun on eye and the first person singular, which is already in play as the poem's first sign after the title. The linguistic images, then, pass through the "I" and the "eye". Since language itself is what has to pass through the needle's eye, the poem can be read as an allegory of the difficulties of communication, which, in turn, connects with the angst of the lyrical "I" or "eye". The cramped situation seems thus to be conditioned by the difficulties of reaching out through language, thus undermining communication and 
threatening to enclose the human subject in a suffocating, claustrophobic isolation.

All of this, notably, is specific to the English version of the poem: a similar reading of the German one would play out quite differently. For instance, the German poem is in the present tense ("es ist") rather than the past ("it was"); the title line is a firm indicative, which is instead undermined in retrospect by "als läge"; and the eye of the needle, moreover, is an ear: the German "Öhr" derives from "Ohr" and is thus related to the faculty of hearing rather than that of vision. The German word "Himmel" has religious connotations, which are lacking in the English "sky", and which give a different resonance to the biblical intertext. These minute differences in "die Art des Meinens" of the two languages - to borrow Walter Benjamin's phrase (Benjamin 1991: 14) which are likely to be insignificant in everyday speech, are precisely what forms the focus of attention for Sebald's differential poems. My point is not that all the meanings suggested by the above interpretation are essential to the poem, but that the question of interpretative license itself is. The coexistence of the casually prose-like and the poetically overdetermined raises the question of the border between significant and insignificant detail, but without giving any hints as to the optimal calibration of our interpretative instruments.

Interestingly, the continuous movement from simplicity at a distance to the dizzying details seen in a close-up is very much present in Jaray's accompanying painting to this poem: its structure can be understood as the visual counterpart of that prescribed move from distant viewing to close scrutiny (fig. 3). Like all the paintings in For Years Now, this one gives a first impression of great simplicity. Two fields in a subdued cyan tint - one to the left, one to the right with a check pattern of white squares covers most of the image. The upper halves of the two fields lean in towards the middle of the image, forming between them a pointy rocket- or pencil-shaped white area, which takes up approximately a fifth of the image's surface. Seen at a distance, the pattern of small white squares - literally thousands of them - appears to be mechanically repetitive. But on closer inspection, it is full of minute irregularities, possibly the traces of the graph paper used for the templates, which reveal it as manually executed. ${ }^{3}$ Thus, the seeming simplicity and regularity of the surface gives way

3 Richard Davey notes a similar network of lines "within the white squares of This Then... (2001) from the series of 'Sebald Prints', caused by the residual presence of the graph paper on which their templates were drawn. They provide a palimpsest of Jaray's practice that mirrors the layers of memory and history that are such a significant presence in W. G. Sebald's writings." (Davey 2014: 26) 
to a vertiginous multitude of detail as soon as the viewer adjusts to a closer look.

Something similar could be said about the painting's relation to iconic reference. As Sebald's words are projected onto this ostensibly abstract image, it begins to partake, as it were, of their referentiality. Interpreted together with "It was as if", the white opening in the middle of this painting could be seen as if it were an extreme magnification of the upper half of a stylized needle's eye. Only "as if", of course: it will not yield completely to figurativity, but keeps insisting on its material, non-representational presence. Interpreted as an image of the eye of a needle, the painting is in and of itself a vision of an excessive close-up: in order to see the eye of a needle in this fashion - as too big even to fit into one's field of vision; there is room only for the upper half - one's optical instrument needs to be set to a level of almost absurd detail.
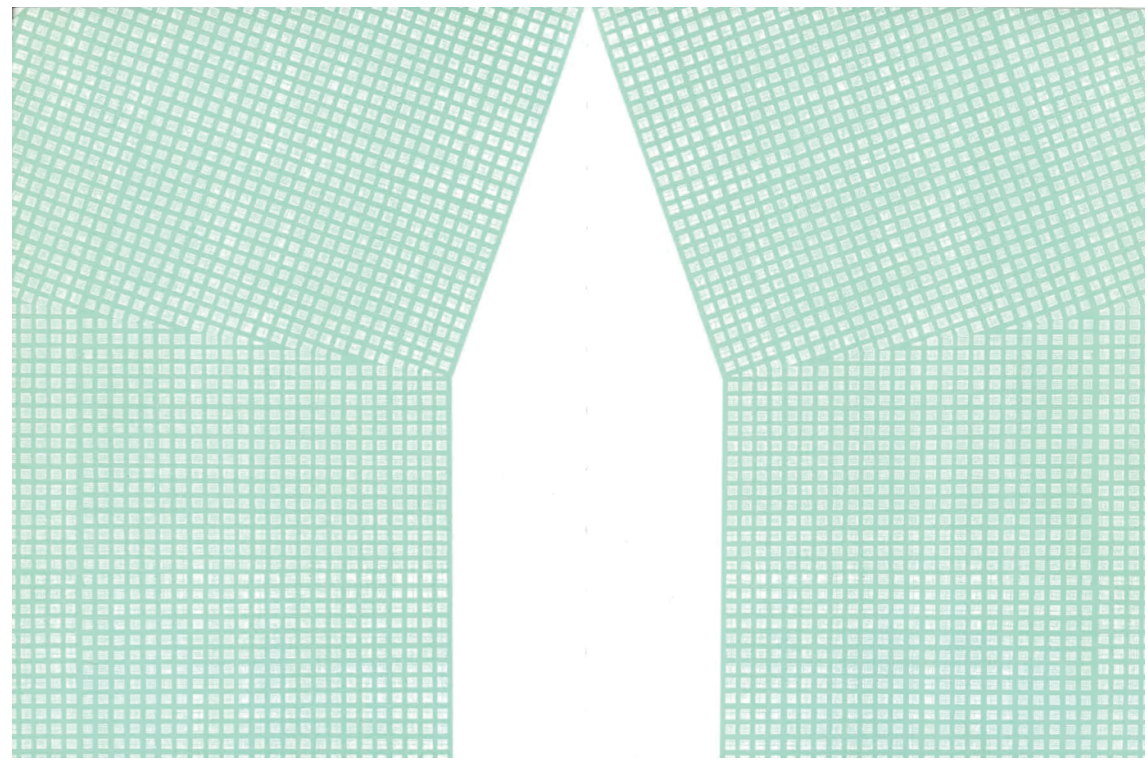

Fig. 3. Tess Jaray, painting accompanying the poem "It was as if" (Sebald 2001: 58-59)

Like the particularities of etymology and syntax in the respective language and their potential impact on poetic meaning, the movement from distant gazing to close scrutiny (and from the non-figurative to the figurative) becomes preeminently visible at the intersection of the artists' images and Sebald's words. It is in such differential spaces - in the gap between the words and images or 
ENGLUND

between the peculiarities of English and German, and in the open-ended and unfinished quality suggested by the parallel versions - that For Years Now and Unerzählt pose their most interesting questions.

\title{
Light and Darkness
}

While the differences between the two poems above may invite the assumption that the English and German poems are essentially identical and the differences irrelevant, the relation between the following two poems is more strikingly puzzling. Here too, one is from For Years Now, the other from Unerzählt, both allegedly quoting Robert Schumann:

\author{
Feelings \\ my friend \\ wrote Schumann \\ are stars \\ which guide us \\ only under \\ a dark sky
}

(Sebald 2001: 48)

\author{
Gefühle \\ mein Freund \\ schrieb Schumann \\ sind Sterne die nur \\ am lichten Tage \\ uns leiten
}

(Sebald 2003: 17)

Not only is the diametrical opposition of the observations baffling, but the fact that they are presented as quotations is also likely to distress the scholarly critic. In the light of this, the temptation to resolve the dissonance by intertextual reference and poetic genesis is quite understandable. Such, for instance, was Hamburger's initial impulse: "Confronted with this contradiction, at first I thought that I must trace the source of this quotation from Schumann, but 
could not find it in the small selection I happen to possess from Schumann's copious writings on music, his journals and letters" (Sebald 2004: 8). Schütte, meanwhile, has approached the task with better results (see Schütte 2013: 127). First of all, Sebald is quoting himself. The first stanza of the unpublished poem "Poesie für das Album", reads thus:

\author{
Gefühle mein Freud \\ schrieb Schumann \\ sind Sterne die bloß \\ bei hellem Himmel \\ leiten aber die Vernunft \\ ist eine Magnetnadel \\ die das Schiff treibt \\ bis es zerschellt
}

(Sebald 2008: 52)

The origin of the quotation, moreover, is a letter of Schumann's, sent in 1827 to his friend Emil Flechsig. What Schumann wrote in this letter, up to and including "Schiff", is quoted verbatim in Sebald's unpublished poem: "Gefühle, mein Freund, sind Sterne, die blos [sic] bei hellem Himmel leiten, aber die Vernunft ist eine Magnetnadel, die das Schiff noch ferner führt, wenn jene auch verborgen sind und nicht mehr leuchten" (Schumann 1910: 3). To make matters even more complicated, Schumann's own sentence is an unacknowledged quotation from Jean Paul's novel Flegeljahre (Schütte 2013: 127).

If one would want to seek a resolution to the contradiction of Sebald's poems by intertextual means, it actually seems quite straightforward. The word "hell" has two meanings in German: "light" and "clear", the latter of which is less immediate but more pertinent in Sebald's sources. In Schumann, Jean Paul and Sebald's earliest version, the adjective refers to a clear sky, which is necessary for the stars to be visible (thus contrasting their guidance against the magnetic needle, which is failsafe and independent of the weather). This kind of genetic explanation, however, directs us away from the poems' actual appearance and their strange contradiction to find a resolution elsewhere. The fact is that for whatever reason - coincidental or deliberate - Sebald's later German micropoem picks up the more common, yet in the context counterintuitive, meaning of "hell" as light ("am lichten Tage"), thus moving from the opposite of cloudy to the opposite of dark, while the English version, 
in turn, inverts that light into darkness. By authorizing the publication of two contradictory versions - one in English, one in German - with two different artists, Sebald thus composed a differential poem, the dissonance of which remains intact regardless of what the "original" quotation said.

The aporetic symbiosis of the poems illustrates the deficiency of any reading that assumes that the common denominator - the fixed stars - is all that matters to an interpretation of a poem. The fact that the atmospheric conditions change from "am lichten Tage" to "under / a dark sky" obviously does not allow for the conclusion that the play of light/darkness and day/ night is irrelevant: not only because it is the immediate focal point of any comparison between the versions of the poem, but also because both explicitly state that this does matter: it is "nur" and "only" under those conditions that feelings give guidance. Schütte is thus right to suggest that the poems' contrast against each other is significant in and of itself: they are best understood as engaged in a dialogue with each other. ${ }^{4} \mathrm{His}$ reading of the contrast points to the "zunehmende Verdüsterung von Sebalds Verfassung", and with reference to Schumann's mental illness, he understands the dark sky as a metaphor for this "psychische Verdüsterung" (Schütte 2013: 124). While certainly pertinent, this reading leaves many aspects of the poems' interrelation unconsidered. Why are feelings more likely to offer counsel in a depressive state? And is the bright day of the German poem to be read according to the same scale: that is, as a marker of carefree times? Hamburger, on his part, concludes that "what is significant in the contradiction is Sebald's reinterpretation of Schumann's words for the purpose of his collaboration with two artists so different", without dwelling on what either the purpose or the reinterpretation might actually be (Sebald 2004: 8).

Meanwhile, Tess Jaray, who also notes the contradiction in her collection of essays, reflects on it from the perspective of the visual artist. Untroubled by academic rigour and textual genesis alike, she is in a position to savour its evocative force and put it in her service as a painter without explaining it: "These two evocations of light and darkness seem to me to be unfathomable poetic mysteries, that in some strange way represent a truth even though they seem to be in opposition." (Jaray 2010: 50) To Jaray, this truth - which she takes care not to pin down in words - has to do precisely with the difference between situations of light and darkness. To express it, she makes a list, which amounts to a poem of her own:

4 "Durch die markante Veränderung führen die beiden Gedichte, die als Dialogpartner von Bilder angelegt sind, selbst einen Dialog miteinander, in dem nicht weniger verhandelt wird als die grundlegende Sicht auf die Welt [...]” (Schütte 2013: 124). 
W. G. Sebald's Late Lyrics Between Words, Images and Languages

Being outside in the dark, looking into light.

Being outside in the light, looking into darkness.

Being inside in the dark, looking out at light.

Being inside in the light, looking out at darkness. (Jaray 2010: 51)

Mechanically symmetrical and dichotomous though it is in its conception, this quatrain hints at what I take to be a crucial aspect of the constellation of the two poems: taken together, they thematize vision's dependence on contrast, on the perceptible difference between figure and ground. ${ }^{5}$ Reading them after one another is like flicking a switch off and on, keeping the stars and their guidance as a constant element, while conditions of light and language change around them. In this sense, the constancy of the stars shines through only the when the two poems are placed together in a constellation: they remain in place while the light comes and goes. Their ability to lead the way, of which each poem speaks, also depends on this constancy. It is the unchanging quality of the stars that turns them into a reliable grid or pattern against which all that is contingent can be measured. To navigate by the stars - correctly reading the world - is to trust in their eternally stable position. At the same time, each poem not only fuses, by way of metaphor, the stars with that which changes in the most capricious manner - feelings - but also points to the limit of their guidance. The conditioning of their reliability (by drawing attention to the situations in which they may not lead the way) is the gist of each sentence.

The contrast between these poems, between light and darkness, is also mirrored by a thematization of significant contrast within each poem. The difference and non-difference between figure and background is the fulcrum on which the poems' meanings turn. The stars' capacity to guide us depends, in the "night" poem, on the contrast between the dark sky and the bright stars. This is logical enough. The "day" poem, however, is in and of itself rather more puzzling. Here, it is precisely the absence of such contrast that guarantees the same capacity. Set against a dark sky the stars are seen, while in the light of day, of course, they are invisible. Hence, the German poem suggests that "Gefühle" are like stars, yet different in this one regard: they lead the way only when they cannot be discerned. The guidance of feelings thus becomes conditioned on their not being fully recognizable or articulated to those who feel. Much as

Jaray's painting, which accompanies the English poem, picks up the evocation of a bright figure against a dark background: it is a very dark green, almost anthrachite, against which a grid-like pattern of 68 white dots stand out. 
Jaray observes about Sebald's poems, they show the way only by dint of their mystery.

When Sebald set out to collaborate with both Jan Peter Tripp and Tess Jaray, and delivered to the two artists contrasting versions of the same poems in different languages, without informing either one about his dealings with the other, he created a peculiar situation for his readers. What I have tried to suggest above is a way of approaching this situation as a potential rather than a problem. By allowing his poems to appear in various guises, Sebald deliberately avoided the treatment of poetry as a fixed and finished product, and turned it into a work in progress, thus circumventing the problems he perceived in the genre of lyric poetry. Accordingly, an interpretative reading that wishes to do justice to his micropoems cannot approach it by postulating a work that is not in progress, whether by deciding that one of these versions is the final and proper one, or by considering the common denominators of the various versions as essential and their differences as accidental. Instead, it is from a perspective that embraces differential quality - by searching for meaning in their differences rather than in their overlaps - that their most intriguing qualities come to the fore, allowing us to see in Sebald not a novelist who did not care for poetry, but a writer who did something truly original with every genre at which he tried his hand.

\author{
Axel Englund \\ axel.englund@littvet.su.se \\ Institutionen för Kultur och Estetik \\ Stockholms universitet \\ 10691 Stockholm \\ SVERIGE
}

\title{
References
}

Adams, T. 2004. The eyes have it. - The Guardian, 19.09.04.

Benjamin, W. 1991. Die Aufgabe des Übersetzers. - Gesammelte Schriften, Band IV. Kleine Prosa. Baudelaireübertragungen, ed. Tillman Rexroth. Frankfurt am Main: Suhrkamp, 9-21.

Corkhill, A. 2009. Angels of Vision in Sebald's After Nature and Unrecounted. - G. Fischer, ed., W. G. Sebald: Schreiben Ex Patria. Amsterdam: Rodopi, 347-368. 
W. G. Sebald's Late Lyrics Between Words, Images and Languages

Davey, R. 2014. Moving through Space. - Doro Globus, ed., The Art of Tess Jaray. London: Ridinghouse, 12-28.

Englund, A. 2013. Readings in the Mist: Two November Poems by W. G. Sebald. - The German Quarterly, 86/3, 275-293.

Englund, A. 2013. Bleston Babel: Migration, Multilingualism and Intertextuality in W. G. Sebald's Mancunian Cantical. - A. Englund, A. Olsson, eds., Languages of Exile: Migration and Multilingualism in Twentieth-Century Literature. Oxford, Bern etc.: Peter Lang, 261-280.

Englund, A. 2014. British Rail Katabasis: W. G. Sebald's “Day Return”. - German Life and Letters, 67/1, 120-137.

Görner, R. 2003. After Words: On W. G. Sebald's Poetry. - R. Görner ed., The Anatomist of Melancholy: Essays in Memory of W. G. Sebald. Munich: Iudicium, 75-80.

Hamburger, M. 2007. W. G. Sebald als Dichter: Drei Annäherungen. - I. Galbraith, ed., Pro Domo: Selbstauskünfte, Rückblicke und andere Prosa. Vienna: Folio, 109123.

Jaray, T. 2010. Painting: Mysteries \& Confessions. London: Lenz Books.

Perloff, M. 2006. Screening the Page/Paging the Screen: Digital Poetics and the Differential Text. - A. Morris and T. Swiss, eds., New Media Poetics: Contexts, Technotexts, and Theories. Cambridge and London: MIYT Press, 143-164.

Schumann, R. 1910. Jugendbriefe, ed. Clara Schumann, $4^{\text {th }}$ ed. Leipzig: Breitkopf und Härtel.

Schütte, U. 2013. Figurationen: Zum lyrischen Werk von W. G. Sebald. Eggingen: Edition Isele.

Sebald,W. G. 2000. Logis in einem Landhaus. Frankfurt am Main: Fischer Taschenbuch Verlag.

Sebald, W. G. and Jaray, T. 2001. For Years Now. London: Short Books.

Sebald, W. G. and Tripp, J. P. 2003. Unerzählt. München: Hanser Verlag.

Sebald, W. G. 2004. Unrecounted, trans. Michael Hamburger. New York: New Directions, 7-10.

Sebald, W. G. 2008. Über das Land und das Wasser, ed. Sven Meyer. Munich: Hanser. 